\title{
VEGETATIVE DEVELOPMENT OF EUROPEAN PEAR WITH QUINCE AND DIFFERENT APPLICATION FORMS OF NUTRIENTS ${ }^{1}$
}

\author{
FABIANE NUNES SILVEIRA ${ }^{2}$, AIKE ANNELIESE KRETZSCHMAR ${ }^{3}$, \\ BRUNO DALAZEN MACHADO ${ }^{4}$, DAIANE CORREA ${ }^{5}$, LEO RUFATO $^{6}$
}

ABSTRACT - The pear consumption in Brazil is significant and the country is dependent on the import of this fruit to meet the internal market. The aim of this study was to evaluate the vegetative growth of European pear trees grafted on quince with two application forms of nutrients. The study was conducted during the 2012/2013, 2013/2014 and 2014/2015 harvests, in the experimental area of the Universidade do Estado de Santa Catarina / UDESC, in Lages. The cultivars used were Rocha, Santa Maria and Abbé Fétel. The quinces were 'Adams' and 'EMA'. The application forms of the nutrients were conventional and fertigation. The experiment was carried out in a randomized block design and the arrangement of treatments was sub subdivided plots. The application form of nutrients and rootstocks of quince little influenced on the vegetative growth of the plants, being more influenced by the scion in the soil conditions of this study. Index terms: Pyrus communis L., fertigation, vigor, Cydonia oblonga L., sectional area of the stem, solid fertilizer.

\section{DESENVOLVIMENTO VEGETATIVO DE PEREIRAS EUROPEIAS COM MARMELEIROS E DIFERENTES FORMAS DE APLICAÇÃO DOS NUTRIENTES}

\begin{abstract}
RESUMO - O consumo de pera no Brasil é expressivo, e o País é dependente da importação dessa fruta para atender ao mercado interno. O objetivo deste trabalho foi avaliar o desenvolvimento vegetativo de pereiras-europeias enxertados em marmeleiros com duas formas de aplicação dos nutrientes. O estudo foi conduzido durante as safras de 2012/2013, 2013/2014 e 2014/2015, na área experimental da Universidade do Estado de Santa Catarina-UDESC, em Lages. As cultivares avaliadas foram Rocha, Santa Maria e Abbé Fétel com os portaenxertos de marmeleiros 'Adams' e 'EMA' e utilizando a aplicação sólida dos nutrientes e via fertirrigação. $\mathrm{O}$ experimento foi conduzido no delineamento em blocos casualizados, e o arranjo dos tratamentos foi em parcelas subsubdivididas. A forma de aplicação de nutrientes e os porta-enxertos de marmeleiro pouco influenciaram no crescimento vegetativo das plantas, sendo esse mais influenciado pela cultivar-copa nas condições edáficas do presente estudo.
\end{abstract}

Termos para indexação: Pyrus communis L., fertirrigação, vigor, Cydonia oblonga L., área de seção do tronco, adubação sólida.

\footnotetext{
'(Paper 272-15). Received December 08, 2015. Accepted July 01, 2016.

${ }^{2}$ Agronomist, Dr. in Plant Production, CAV/UDESC. Lages - SC. Professor at the Federal Institute of Education, Science and Technology, IFSC. Urupema - SC. E-mail: fabianenunessilveira@gmail.com

${ }^{3} \mathrm{Dr}$. in Fruticulture, Advisor, Professor of the Department of Agronomy, CAV/UDESC. Lages - SC. Research Productivity Scholarship of CNPq. E-mail: aike.kretzschmar@udesc.br

${ }^{4}$ Dr. in Plant Production, Professor at the Federal Institute of Education, Science and Technology, IFSC. Urupema - SC. E-mail: bruno. dalazem@ifsc.edu.br

${ }^{5}$ Agronomist, PhD in Plant Production, CAV/UDESC. Lages - SC. E-mail: daicorea@hotmail.com

${ }^{6}$ Dr. in Fruticulture, Professor of the Department of Agronomy, CAV/UDESC. Lages-SC. Research Productivity Scholarship of CNPq. E-mail: leoruffato@yahoo.com.br
} 


\section{INTRODUCTION}

The Brazilian fruit cultivation is recognized worldwide as one of the most diversified, however, the pear cultivation in Brazil does not stand out. The pear is, among the fruits of temperate climate, the one that has the least expression in terms of cultivated area, production and production value (FIORAVANÇO, 2007). However, its domestic consumption is significant, making it the third biggest importer of fruit in the world (USDA/FAS, 2015), which makes this crop an excellent market opportunity for domestic producers (FACHINELLO et al., 2011).

One of the limiting factors of economically satisfactory production is in the definition of cultivars and rootstocks adapted to the different potentially producing regions (MACHADO et al., 2013). Most of the pear cultivars in Brazil use the P. calleryana (Decne.) rootstock, which provides plants with high vigor and slow production period (GIACOBBO et. al., 2007). The emergence of different quince clones (Cydonia oblonga) provided lower plant vigor and rapid fruiting (MILOSEVIC; MILOSEVIC, 2011); however, the quince root system is considered superficial and poorly expanded, with about $80 \%$ of the roots concentrated in the first $40 \mathrm{~cm}$ of depth (MACHADO, 2014).This characteristic of their root system gives the plants weak support to the soil, needing the installation of support systems and irrigation systems due to the greater stress of the plants in periods of low precipitation (ALMEIDA, 2014).

The drip irrigation system is adapted to the production conditions of the pear tree grafted to quince in the south of Brazil, in addition to making possible the use of fertirrigation considered one of the most efficient methods in providing nutrients for fruit trees (NEILSEN; NEILSEN, 2008).

Fertigation is used in Belgium and the Netherlands in Conference pears to increase the efficiency of nutrient absorption and to maximize the fruit production (PIETER et al., 2013). The nitrogen fertigation in the pear crop has the potential to reduce its losses and to increase its absorption efficiency, since the $\mathrm{N}$ presents high mobility in the soil profile, being absorbed through mass flow (RAIJ, 2011). Research carried out with fertigation in the pear crop has shown an increase in the efficiency of $\mathrm{N}$ absorption, reducing the amount applied up to $23 \%$ and its losses in $45 \%$ in orchards in China (YIN et al., 2012).

The process of phosphorus absorption in the soil occurs $95 \%$ by the diffusion mechanism, in which the volumetric humidity of the soil is the most important factor to promote its absorption by the roots (NEILSEN; NEILSEN, 2008). In Spadona pear, the fertigation with $P$ increased the concentration of this ion in the soil significantly when compared to the solid application of the nutrient (KLEIN et al., 1999). Higher fertigation frequencies with $\mathrm{N}$ and $\mathrm{P}$ in pear orchards may increase the efficiency of nutrient use compared to the application of solid fertilizers in the soil surface (YIN et al., 2007).

In Brazil, there is a lack of information related to the use of irrigation and/or fertigation systems for pear cultivation and its use in orchards with the use of quince (Cydonia oblonga). Therefore, the aim of this study was to evaluate the vegetative development of European pear cultivars grafted on quince with two forms of nutrient application in the region of Planalto Serrano, state of Santa Catarina, during the 2012/13, 2013/14 and 2014/15 harvests.

\section{MATERIALS AND METHODS}

The experiment was conducted during the 2012/13, 2013/14 and 2014/15 harvests, in the experimental area of the State University of Santa Catarina/UDESC, at the Agroveterinary Sciences Center/CAV, in the municipality of Lages, Santa Catarina, at $938 \mathrm{~m}$ of altitude, $27^{\circ} 19^{\prime} 44^{\prime \prime}$ of latitude and $50^{\circ} 19^{\prime} 44^{\prime \prime}$ of longitude. The climate, according to Köppen classification, is the $\mathrm{Cfb}$ type, temperate and humid climate with fresh summer and average annual temperature of $14.3^{\circ} \mathrm{C}$, with average annual rainfall of $1.479 \mathrm{~mm}$ (CARDOSO et al., 2003).

The soil of the experimental area is classified as Cambisol Humic Aluminum leptic (EMBRAPA, 2013), with free texture, moderate A horizon and substrate composed of siltstones and argillites (BERTOL, 2002). The soil physico-chemical analyzes carried out in 2007 indicated the following results: $\mathrm{pH}$ in water of 4.8 ; SMP index of $5.1 ; 11.2 \mathrm{mg}$ $\mathrm{dm}^{-3}$ of P; $165 \mathrm{mg} \mathrm{dm}^{-3}$ of K; $2.0 \mathrm{cmol}_{\mathrm{c}} \mathrm{dm}^{-3}$ of Ca; 1.1 $\mathrm{cmol} \mathrm{dm}{ }^{-3}$ of Mg; $4.1 \%$ of organic matter and $35 \%$ of clay. In the implantation of the experiment, the initial preparation of the soil with plowing and harrowing was carried out. In order to correct the acidity, liming was carried out in soil, in order to raise the soil $\mathrm{pH}$ in water to 6.0. In the correction fertilization, $\mathrm{K}_{2} \mathrm{O}$ and $\mathrm{P}_{2} \mathrm{O}_{5}$ were applied when necessary, following the recommendation of the Soil Chemistry and Fertility Committee RS/SC (2004).

The experimental area was implanted in 2008, with pre-formed seedlings consisting of the Rocha, Abbé Fétel and Santa Maria European pear 
cultivars grafted on the Adams and EMA quince rootstocks. The company Frutirol Agrícola Ltda, located in Vacaria, RS, supplied the seedlings. The planting spacing used was $3.0 \mathrm{~m}$ between rows and $1.0 \mathrm{~m}$ between plants, resulting in a planting density of 3,333 plants/ha. The plants were conducted in the central leader system and the cultural treatments consisted in the accomplishment of fertilization, bending of branches, crowning, pruning, control of weeds and pests, according to the technical recommendations of the crop (NAKASU et al., 2007). The irrigation system was installed in the dormancy period of the plants in 2011, using the localized system by drip. The irrigation management used was the same in both treatments (solid nutrient application and via fertirrigation) in order to maintain soil tension levels in values close to $10 \mathrm{kPa}$. The monitoring of the need for irrigation was carried out using puncture tensiometers placed in the soil, at depths corresponding to layers from 0 to 0.20 and from 0.20 to $0.40 \mathrm{~m}$.

In the 2011/12 harvest, soil samples were collected again for the physical-chemical analyzes that indicated: $\mathrm{pH}$ in water of 5.2; SMP index of $5.8 ; 5.0 \mathrm{mg} \mathrm{dm}^{-3}$ of P Mehlich; $89.0 \mathrm{mg} \mathrm{dm}^{-3}$ of K ; $4.0 \mathrm{cmol}_{\mathrm{c}} \mathrm{dm}^{-3}$ of $\mathrm{Ca} ; 2.9 \mathrm{cmol}_{\mathrm{c}} \mathrm{dm}^{-3}$ of $\mathrm{Mg}$; CEC effective of $7.6 \mathrm{cmol}_{\mathrm{c}} \mathrm{dm}^{-3}, 3.3 \%$ of organic matter and $36 \%$ of clay. The total fertilizer applied in the treatments with solid application in the surface and via fertigation was estimated based on the soil analysis carried out in the 2011/12 harvest, using 42 $\mathrm{kg} \mathrm{ha}^{-1}$ of $\mathrm{KCl}$ - potassium chloride $\left(60 \%\right.$ of $\left.\mathrm{K}_{2} \mathrm{O}\right)$ and $295 \mathrm{~kg} \mathrm{ha}^{-1}$ of MAP- monoammonium phosphate $\left(10 \%\right.$ of $\mathrm{N}$ and $48 \%$ of $\left.\mathrm{P}_{2} \mathrm{O}_{5}\right)$. In the application of the nutrients in the solid form, 44 grams of MAP and 6 grams of $\mathrm{KCl}$ per plant were distributed in the canopy projection area in May, and the same fertilization was repeated in October. In the fertirrigation, the same amounts of nutrients were applied, but in a piecemeal way, divided into a weekly application in the months from May to June and from October to December, totaling 20 applications. The nutritive solution applied via fertigation was balanced so that the plants submitted to the fertirrigated treatment received the same amounts of nutrients as the plants submitted to the application in the solid form of the fertilizers. The application of the nutrients in the fertigation system was carried out by direct suction through a Venturi injector, with permanent agitation directly in the fertilizer dissolution tank.

During the 2012/13, 2013/14 and 2014/15 harvests, foliar fertilization was carried out in all plants of the experimental area with boron $(0.4 \%)$; two applications, calcium $(0.6 \%)$; six applications and magnesium (2\%); three applications carried out in the period from October 15 to January 15 at biweekly intervals.

The experiment was conducted in a randomized complete block design with three replicates and the treatment arrangement was in subsubdivided plots. The cultivar factor constituted the main plots: Rocha, Abbé Fétel and Santa Maria. The rootstocks factor was allocated in the subplots: Adams and EMA quince. The form of nutrients application factor composed the sub-subplot: application in solid form on the surface and application via fertigation. Each sub-subplot was constituted by ten plants.

The evaluation of the vegetative development was carried out during the plant rest period. The sub-subplots were composed by ten plants, being the central six plants considered as useful and the following parameters being evaluated: a) crosssectional area of the rootstock trunk (CSART), obtained by the equation CSART $=\pi \mathrm{d}^{2} / 4$, where $\mathrm{d}$ is the trunk diameter of the plants measured with a digital caliper $5.0 \mathrm{~cm}$ below the grafting point; $\mathrm{b}$ ) cross-sectional area of the trunk of the cv. canopy (CATC), obtained by the CATC equation $=\pi \mathrm{d}^{2} / 4$, where $d$ is the trunk diameter of the plants measured with a digital caliper, $5.0 \mathrm{~cm}$ above the grafting point; c) plant height $(\mathrm{m})(\mathrm{PH})$, obtained with a measuring tape, from the neck of the plant to the apex of the main branch; d) canopy volume $\left(\mathrm{m}^{3}\right)(\mathrm{CV})$, obtained by considering the plant canopy as a cone, through the formula $\mathrm{CV}=(\pi \times \mathrm{T} \times \mathrm{W} \times \mathrm{h}) / 3$, where $\mathrm{T}$ is the plant thickness (m), W is the width of the plant (m), and $h$ is the plant height from the insertion of the first branches ( $\mathrm{m}$ ) to the apex of the central leader; e) buds index (buds number/ $\mathrm{cm}_{\text {branch }}{ }^{-1}$ ) (BI), obtained through the relation between the number of buds and the length of the branch.

The data were submitted to analysis of variance and the averages analyzed by the Tukey test at $5 \%$ probability, using the Winstat 2.0 program.

\section{RESULTS AND DISCUSSION}

The vegetative characteristics were significantly influenced by the cultivars used. The Abbé Fétel showed higher plant height $(\mathrm{PH})$ in the first harvest and greater cross section area of the rootstock trunk (CSART) in the three harvests, comparing to Rocha and Santa Maria (Table 1).

The plant vigor is directly correlated with the cross-sectional area of the trunk of the cv. canopy (CATC) measured at $5 \mathrm{~cm}$ above the point of grafting (CZYNCZYK; BIELICKI, 2012), this CATC was superior in cv. Abbé Fétel (Table 1). Several authors 
report the high vigor pattern of Abbé Fétel (TOMAZ et al., 2009; MUSACCHI et al., 2011; GALLI et al., 2011; MACHADO et al., 2013; PETINELI, 2014).

The development of branches in the canopy of the plants differed significantly between the cv. canopies. Based on the canopy volume (CV), the cvs. Abbé Fétel and Rocha showed superior CV than the Santa Maria in the three harvests. The plant height $(\mathrm{PH})$ was influenced by $\mathrm{cv}$. canopy, being superior in Abbé Fétel in the first year of evaluation but not differing from Rocha in the two subsequent years (Table 1). As observed in the field, Abbé Fétel showed more vigorous plants characterized by the erect height with greater development of apical dominance, which may have caused the formation of tall canopy with long branches and with a larger number and size of leaves. The estimated productivity in Abbé Fétel in this study was very low $\left(0.39 \mathrm{t} \mathrm{ha}^{-1}, 0.01 \mathrm{t} \mathrm{ha}^{-1}\right.$ and $0.52 \mathrm{t} \mathrm{ha}^{-1}$ during the three harvests, respectively), and this behavior was also observed in Vacaria/RS. The coincidence of the flowering season of Abbé Fétel with cv. Rocha and Santa Maria and the absence of pollinators within the orchard are some of the factors that associated with its excessive plant vigor may have compromised the production of Abbé Fétel fruits, considering that the estimated yield of the cultivars did not differ in relation to the effect of the application of nutrients in any harvest. This vigorous growth of the Abbé Fétel shoot and the consequent canopy shading negatively affected the formation of vegetative and reproductive structures determined through the buds index (BI), being the lowest observed in Abbé Fétel in the first and third year of evaluation (Table 1).This result was already expected, since, according to Rufato et al. (2012) the bud index is inversely proportional to the vegetative growth of the plant. According to Pasa et al. (2011), the formation of buds suffers greater competition for carbohydrates in vigorous plants, because branches of high vigor have greater apical dominance, influencing the hormonal and nutritional balance; differently from the Rocha plants, which were characterized by the semi-erect height with greater light interception of the branches located inside the canopy, which provided a better balance in the plant vegetative/productive relation with significant additions in the bud index of this cv. in two harvests (Table 1). This adequate balance resulted in significantly higher estimated yields in the Rocha cultivar (2.39 tha $\mathrm{t}^{-1}, 1.85 \mathrm{t} \mathrm{ha}^{-1}$ and $5.03 \mathrm{t} \mathrm{ha}^{-1}$, respectively in the 2012/13, 2013/14 and 2014/15 harvests), when compared to the Abbé Fétel and Santa Maria cultivars in the three harvests, although considered low for this crop.
The cross-sectional area of the rootstock trunk (CSART) and the cross-sectional area of the trunk of the cv. (CATC) were influenced by quince. The Adams provided superior vigor in relation to the CSART and the CATC in the three-year evaluation (Table 2). Results verified by Almeida (2014) also report greater vigor of Adams compared to $E M A$. However, the differences induced by rootstock in plant vigor may vary according to the climatic conditions of each site (LEPSIS; DRUZE, 2011; ALMEIDA, 2014), or due to changes in soil type, nutrient absorption and translocation to the shoot (BAKSHI; SINGH, 2010), on the compatibility of grafting due to the movement of sap in xylem and phloem (FACHINELLO; PASA, 2010; PETINELI, 2014) And also according to the cultivar used (STERN; DORON, 2009; PASA et al., 2012; IKINCI et al., 2014), and other factors. This explains why the rootstock had an influence on the CSART and the CATC and, however, did not affect the plant height $(\mathrm{PH})$ and the bud index (BI) (Table 2) over the three evaluated years.

The nutritional status of the plant is a determining factor in pear growth and development. The fertigation is considered an efficient method of supplying nutrients to fruit trees (NEILSEN; NEILSEN, 2008). Regarding the nutrient application, fertigation had a negative effect on the $\mathrm{BI}$ in the first year, but increased $\mathrm{PH}$ in the second year of evaluation only (Table 3 ).

The application form did not change the CATC and CV in the three evaluation years (Table 3 ) and the differences for the $\mathrm{PH}$ and the BI were verified in only one of the three evaluated years, which leads to inconsistent results in relation to the influence of the nutrient application forms in pear growth and development. Similar results related to the lack of the application form effect were also verified by Yin et al. (2009) with 'D'Anjou pear, in relation to the application of $\mathrm{N}$ and $\mathrm{P}$ in the solid form on the surface and via fertirrigation. In the following study, the authors did not verify differences regarding the use of the two application forms of $\mathrm{N}$, in the growth of the plants, in the production and the size of the pear fruits (YIN et al., 2012). The application of fertilizers also did not alter the growth of Conference and Lukasowka pear on EMA (LIPA; SZOT, 2013). 
TABLE 1 - Cross-sectional area of the rootstock trunk (CSART), cross-sectional area of the trunk of the cv. canopy (CATC), plant height (PH), canopy volume (CV) and bud index (BI) for the different European pear canopy cultivars in the 2012/13, 2013/14 and 2014/15 harvests.

\begin{tabular}{|c|c|c|c|c|c|}
\hline \multicolumn{6}{|c|}{ 2012/13 Harvest } \\
\hline Cultivars & CSART $\left(\mathrm{cm}^{2}\right)$ & $\operatorname{CATC}\left(\mathrm{cm}^{2}\right)$ & PH (m) & $\mathrm{CV}\left(\mathrm{m}^{3}\right)$ & BI \\
\hline Rocha & $17.45 \mathrm{~b}$ & $11.70 \mathrm{~b}$ & $2.06 \mathrm{~b}$ & $1.75 \mathrm{a}$ & $0.49 \mathrm{a}$ \\
\hline Abbé Fétel & $28.90 \mathrm{a}$ & $19.84 \mathrm{a}$ & $2.18 \mathrm{a}$ & $1.62 \mathrm{a}$ & $0.41 \mathrm{c}$ \\
\hline Santa Maria & $13.54 \mathrm{c}$ & $10.71 \mathrm{~b}$ & $1.73 \mathrm{c}$ & $0.96 \mathrm{~b}$ & $0.46 \mathrm{~b}$ \\
\hline Average & 19.96 & 14.08 & 1.99 & 1.44 & 0.45 \\
\hline CV $(\%)$ & 9.88 & 16.29 & 5.47 & 25.28 & 3.14 \\
\hline \multicolumn{6}{|c|}{ 2013/14 Harvest } \\
\hline Cultivars & CSART $\left(\mathrm{cm}^{2}\right)$ & $\operatorname{CATC}\left(\mathrm{cm}^{2}\right)$ & PH (m) & $\mathrm{CV}\left(\mathrm{m}^{3}\right)$ & BI \\
\hline Rocha & $25.85 \mathrm{~b}$ & $18.46 \mathrm{~b}$ & $2.46 \mathrm{a}$ & $3.74 \mathrm{a}$ & $0.45 \mathrm{~b}$ \\
\hline Abbé Fétel & $37.69 \mathrm{a}$ & $25.88 \mathrm{a}$ & $2.56 \mathrm{a}$ & $3.70 \mathrm{a}$ & $0.50 \mathrm{a}$ \\
\hline Santa Maria & $20.56 \mathrm{c}$ & $14.77 \mathrm{c}$ & $1.98 \mathrm{~b}$ & $1.17 \mathrm{~b}$ & $0.40 \mathrm{c}$ \\
\hline Average & 28.03 & 19.70 & 2.33 & 2.87 & 0.45 \\
\hline CV $(\%)$ & 7.49 & 6.79 & 6.74 & 25.05 & 9.05 \\
\hline \multicolumn{6}{|c|}{ 2014/15 Harvest } \\
\hline Cultivars & CSART $\left(\mathrm{cm}^{2}\right)$ & CATC $\left(\mathrm{cm}^{2}\right)$ & PH (m) & $\mathrm{CV}\left(\mathrm{m}^{3}\right)$ & BI \\
\hline Rocha & $36.00 \mathrm{~b}$ & $26.54 \mathrm{~b}$ & $3.08 \mathrm{a}$ & $4.38 \mathrm{a}$ & $0.42 \mathrm{a}$ \\
\hline Abbé Fétel & $42.72 \mathrm{a}$ & $30.64 \mathrm{a}$ & $3.13 \mathrm{a}$ & $4.26 \mathrm{a}$ & $0.36 \mathrm{~b}$ \\
\hline Santa Maria & $27.72 \mathrm{c}$ & $19.99 \mathrm{c}$ & $2.37 \mathrm{~b}$ & $2.20 \mathrm{~b}$ & $0.33 \mathrm{~b}$ \\
\hline Average & 35.48 & 25.73 & 2.86 & 3.61 & 0.37 \\
\hline CV $(\%)$ & 11.83 & 9.74 & 5.49 & 16.75 & 13.32 \\
\hline
\end{tabular}

*Averages followed by the same letter in column do not differ from each other by Tukey test at $5 \%$ probability.

TABLE 2 - Cross-sectional area of the rootstock trunk (CSART), cross-sectional area of the trunk of the cv. canopy (CATC), plant height (PH), canopy volume (CV) and bud index (BI) for the different quince rootstock in the 2012/13,2013/14 and 2014/15 harvests.

\begin{tabular}{|c|c|c|c|c|c|}
\hline \multicolumn{6}{|c|}{ 2012/13 Harvest } \\
\hline Rootstocks & CSART $\left(\mathrm{cm}^{2}\right)$ & $\operatorname{CATC}\left(\mathrm{cm}^{2}\right)$ & PH (m) & $\mathrm{CV}\left(\mathrm{m}^{3}\right)$ & BI \\
\hline Adams & $22.11 \mathrm{a}$ & $15.83 \mathrm{a}$ & $2.02 \mathrm{a}$ & $1.63 \mathrm{a}$ & $0.45 \mathrm{a}$ \\
\hline EMA & $17.81 \mathrm{~b}$ & $12.34 \mathrm{~b}$ & $1.96 \mathrm{a}$ & $1.26 \mathrm{~b}$ & $0.46 \mathrm{a}$ \\
\hline Average & 19.96 & 14.08 & 1.99 & 1.44 & 0.45 \\
\hline CV $(\%)$ & 9.88 & 16.29 & 5.47 & 25.28 & 3.14 \\
\hline \multicolumn{6}{|c|}{ 2013/14 Harvest } \\
\hline Rootstocks & CSART $\left(\mathrm{cm}^{2}\right)$ & CATC $\left(\mathrm{cm}^{2}\right)$ & PH (m) & $\mathrm{CV}\left(\mathrm{m}^{3}\right)$ & BI \\
\hline Adams & $31.04 \mathrm{a}$ & $21.59 \mathrm{a}$ & $2.35 \mathrm{a}$ & $3.03 \mathrm{a}$ & $0.44 \mathrm{a}$ \\
\hline EMA & $25.03 \mathrm{~b}$ & $17.82 \mathrm{~b}$ & $2.31 \mathrm{a}$ & $2.71 \mathrm{a}$ & $0.46 \mathrm{a}$ \\
\hline Average & 28.03 & 19.70 & 2.33 & 2.87 & 0.45 \\
\hline CV $(\%)$ & 7.49 & 6.79 & 6.74 & 25.05 & 9.05 \\
\hline \multicolumn{6}{|c|}{ 2014/15 Harvest } \\
\hline Rootstocks & $\operatorname{CSART}\left(\mathrm{cm}^{2}\right)$ & CATC $\left(\mathrm{cm}^{2}\right)$ & PH (m) & $\mathrm{CV}\left(\mathrm{m}^{3}\right)$ & BI \\
\hline Adams & $38.99 \mathrm{a}$ & $27.92 \mathrm{a}$ & $2.82 \mathrm{a}$ & $3.53 \mathrm{a}$ & $0.37 \mathrm{a}$ \\
\hline EMA & $31.97 \mathrm{~b}$ & $23.53 \mathrm{~b}$ & $2.90 \mathrm{a}$ & $3.69 \mathrm{a}$ & $0.37 \mathrm{a}$ \\
\hline Average & 35.48 & 25.73 & 2.86 & 3.61 & 0.37 \\
\hline CV $(\%)$ & 11.83 & 9.74 & 5.49 & 16.75 & 13.32 \\
\hline
\end{tabular}

*Averages followed by the same letter in column do not differ from each other by Tukey test at $5 \%$ probability. 
TABLE 3 - Cross-sectional area of the rootstock trunk (CSART), cross-sectional area of the trunk of the cv. canopy (CATC), plant height (PH), canopy volume (CV) and bud index (BI) for the different application forms of nutrients in the 2012/13, 2013/14 and 2014/15 harvests.

\begin{tabular}{|c|c|c|c|c|c|}
\hline \multicolumn{6}{|c|}{ 2012/13 Harvest } \\
\hline Applications forms & CSART $\left(\mathrm{cm}^{2}\right)$ & CATC $\left(\mathrm{cm}^{2}\right)$ & PH (m) & $\mathrm{CV}\left(\mathrm{m}^{3}\right)$ & BI \\
\hline Conventional & $19.5 \mathrm{a}$ & $14.1 \mathrm{a}$ & $2.0 \mathrm{a}$ & $1.4 \mathrm{a}$ & $0.4 \mathrm{a}$ \\
\hline Fertirrigation & $20.4 \mathrm{a}$ & $13.9 \mathrm{a}$ & $1.9 \mathrm{a}$ & $1.4 \mathrm{a}$ & $0.4 \mathrm{~b}$ \\
\hline Average & 19.9 & 14.0 & 1.9 & 1.4 & 0.4 \\
\hline CV $(\%)$ & 9.8 & 16.2 & 5.4 & 25.2 & 3.1 \\
\hline \multicolumn{6}{|c|}{ 2013/14 Harvest } \\
\hline Applications forms & CSART $\left(\mathrm{cm}^{2}\right)$ & CATC $\left(\mathrm{cm}^{2}\right)$ & PH (m) & $\mathrm{CV}\left(\mathrm{m}^{3}\right)$ & BI \\
\hline Conventional & $28.4 \mathrm{a}$ & $19.9 \mathrm{a}$ & $2.2 \mathrm{~b}$ & $2.6 \mathrm{a}$ & $0.4 \mathrm{a}$ \\
\hline Fertirrigation & $27.6 \mathrm{a}$ & $19.4 \mathrm{a}$ & $2.4 \mathrm{a}$ & $3.0 \mathrm{a}$ & $0.4 \mathrm{a}$ \\
\hline Average & 28.0 & 19.7 & 2.3 & 2.8 & 0.4 \\
\hline CV $(\%)$ & 7.4 & 6.7 & 6.7 & 25.0 & 9.0 \\
\hline \multicolumn{6}{|c|}{ 2014/15 Harvest } \\
\hline Applications forms & CSART $\left(\mathrm{cm}^{2}\right)$ & $\operatorname{CATC}\left(\mathrm{cm}^{2}\right)$ & PH (m) & $\mathrm{CV}\left(\mathrm{m}^{3}\right)$ & BI \\
\hline Conventional & $36.4 \mathrm{a}$ & $25.9 \mathrm{a}$ & $2.9 \mathrm{a}$ & $3.8 \mathrm{a}$ & $0.3 \mathrm{a}$ \\
\hline Fertirrigation & $34.5 \mathrm{a}$ & $25.4 \mathrm{a}$ & $2.8 \mathrm{a}$ & $3.3 \mathrm{~b}$ & $0.3 \mathrm{a}$ \\
\hline Average & 35.4 & 25.7 & 2.8 & 3.6 & 0.3 \\
\hline CV $(\%)$ & 11.8 & 9.7 & 5.4 & 16.7 & 13.2 \\
\hline
\end{tabular}

*Averages followed by the same letter in column do not differ from each other by Tukey test at $5 \%$ probability.

\section{CONCLUSIONS}

The Abbé Fétel cultivar has a larger area of the cross section of the rootstock trunk and of the canopy cultivar. The cv. Rocha and Abbé Fétel have higher canopy height and volume; Rocha and Abbé Fétel produce the highest buds index in the branch.

The Adams quince has a larger cross-sectional area of the trunk and induces a larger cross-sectional area of the trunk of the canopy cultivars.

The application of nutrients has no effect on the cross-sectional area of the rootstock trunk and on the cross-sectional area of the trunk of the canopy cultivar. The plant height can be positively influenced by fertigation. With the increase of the plants age, the conventional application of nutrients induces a greater canopy volume in the edaphic conditions and with the management adopted in this study.

\section{REFERENCES}

ALMEIDA, G.K. Avaliação das cultivares Rocha e Abate Fetel enxertadas sobre marmeleiros em Vacaria-RS. 2014. 128 f. Dissertação (Mestrado) Universidade Federal do Rio Grande do Sul, Porto Alegre, 2014.

BAKSHI, P.; SINGH, D.R. Rootstocks. In: SHARMA, R.M.; PANDEY, S.N.; PANDEY, V. (Ed.). The pear: production, post-harvest management and protection. India: IBDC Publishers, 2010. p.147-161.

BERTOL, I.; SCHICK, J.; BATISTELA, O.; LEITE, D.; AMARAL, A.J. Erodibilidade de um Cambissolo Húmico alumínico léptico, determinada sob chuva natural entre 1989 e 1998 em Lages (SC). Revista Brasileira de Ciência do Solo, Viçosa, MG, v.26, p.465-471, 2002.

CARDOSO, C.O.; ULLMANN, M.N.; EBERHARDT, E.L. Balanço hídrico agroclimático para Lages, SC. Revista de Ciências Agroveterinárias, Lages, v.2, n.2, p.118-130, 2003. 
COMISSÃO DE QUÍMICA E FERTILIDADE DO SOLO. Manual de adubação e calagem para os estados do Rio Grande do Sul e de Santa Catarina.10.ed. Porto Alegre, 2004. 400p.

CZYNCZYK, A.; BIELICKI, P. Eleven year evaluation of American (Geneva ${ }^{\circledR}$ ) and Polish rootstocks with 'Golden Delicious Reinders' Apple in Poland. Journal of Fruit and Ornamental Plant Research, Skierniewice, v.20, n.2, p.11-21, 2012.

EMBRAPA - Empresa Brasileira de Pesquisa Agropecuária. Sistema brasileiro de classificação de solos. 3.ed. Brasília, DF: Embrapa Solos, 2013. $353 \mathrm{p}$.

FACHINELLO, J.C.; PASA, M.S.; SCHMTIZ, J.C.; BETEMPS, D.L. Situação e perspectivas da fruticultura de clima temperado no Brasil. Revista Brasileira de Fruticultura, Jaboticabal, v.33, n.1, p.109-120, 2011.

FACHINELLO, J.C.; PASA, M.S. Porta enxertos na cultura da Pereira. In: REUNIÃO TÉCNICA DA CULTURA DA PEREIRA, 3., 2010, Lages. Anais... p.70-77.

FIORAVANÇO, J.C.A cultura da pereira no Brasil: situação econômica e entraves para o seu crescimento. Informações Econômicas, São Paulo, v.37, n.3, mar. 2007.

GALLI, F.; ANCARANI, S.; SERRA, S.; MUSACCHI, S. Training systems and rootstocks for high density planting (HDP) of the cultivar 'Abbé Fétel': developmental trials in Italy, Acta Horticulturae, The Hague, v.2, n.909, 2011.

GIACOBBO, C.L.; FACHINELLO, J.C.; PICOLOTTO, L. Compatibilidade entre o marmeleiro portaenxerto cv. 'EMC' e cultivares de pereira. Scientia Agraria, Curitiba, v.8, n.1, p.33-37, 2007.

IKINCI, A.; BOLAT, I.; ERCISLI, S.; KODAD, O. Influence of rootstocks on growth, yield, fruit quality and leaf mineral element contents of pear cv. 'Santa Maria' in semi-arid conditions. Biological Research, Santiago de Chile, v.47, n.71, p.1-8, 2014.
KLEIN, I.; MEIMON, A.; SKEDI, D. Drip Nitrogen, Phosphorus, and Potassium Fertigation of 'Spadona' Pear. Journal of Plant Nutrition, New York, v.22, n.3, p.489-500, 1999.

LEPSIS, J.; DRUDZE, I. Evaluation of seven pear rootstocks. Acta Horticulturae, The Hague, v.903, p.457-462, 2011.

LIPA, T.; SZOT, I. Effect of fertilization methods on growth of pear trees, yielding and fruit quality. Modern Phytomorphology, Lviv, v.4, p.55-58, 2013.

MACHADO, B. D. Padrões de crescimento e produção de cultivares de pereiras europeias sobre portaenxertos de marmeleiro. 2014. 148 p. (Tese de Doutorado em Produção Vegetal), Universidade do Estado de Santa Catarina, Lages, 2014.

MACHADO, B.D.; RUFATO, L.; BOGO, A.; KRETZSCHMAR, A.A.; MARIO, A.E. Cultivares e porta enxertos sobre o vigor de plantas de pereira europeias. Ciência Rural, Santa Maria, v.43, n.9, p.1542-1545, 2013.

MILOSEVIC, T.; MILOSEVIC, N. Influence of cultivar and Rootstock on early growth and syllepsis in nursery tress of pear (Pyrus communis L., Rosaceae). Brazilian Archives Biology and Technology, Curitiba, v.54, n.3, p.451-456, 2011.

MUSACCHI, S.; SERRA, S.; ANCARANI, V. Comparison among pear training systems and rootstocks for high density planting (HDP) of the cultivar 'Abbè Fetel', Acta Horticulturae, The Hague, v.2, n.909, 2011.

NAKASU, B.H.; HERTER, F.G.; CAMELATTO, D.; REISSER JÚNIOR, C.; FORTES, J.F.; CASTRO, F.A.S.; RASEIRA, A.; FREIRE, C.J.S.; BASSO, C.; FAORO, I.D.; PETRI, J.L.; LEITE, G.B.; PEREIRA, J.F.M.; CANTILLANO, R.F.F.; VERÍSSIMO, V.; SIMÕES, F. A cultura da pera. Brasília, DF: Embrapa Informação Tecnológica, 2007. 58 p.

NEILSEN, D.; NEILSEN, G.H. Fertigation of deciduous fruit trees: apples and sweet cherry. In: IMUS, P.; PRICE, M. R. (Ed.). Fertigation: optimizing the utilization of water and nutrition. Horgen: International Potash Institute, 2008. p.76-88. 
PASA, M.S.; FACHINELLO, J.C.; SCHMITZ, J.D.; SOUZA, A.L.K.; DE FRANCESCHI, E. Desenvolvimento, produtividade e qualidade de peras sobre portaenxertos de marmeleiro e Pyrus calleryana. Revista Brasileira de Fruticultura, Jaboticabal, v.34, n.3, p.873-880, 2012.

PASA, M.S.; FACHINELLO, J.C.; SCHMITZ, J.D.; SOUZA, A.L.K.; HERTER, F.G. Hábito de frutificação e produção de pereiras sobre diferentes portaenxertos. Pesquisa Agropecuária Brasileira, Brasília, DF, v.46, n.9, p.998-1005, 2011.

PETINELI, R. Pereiras europeias enxertadas sobre portaenxerto de marmeleiro: vigor, produção e incompatibilidade de enxertia. 2014. 81 f. Dissertação (Mestrado em Produção Vegetal)- Universidade do Estado de Santa Catarina, Lages, 2014.

PIETER, J.; TOM, D.; FRANK, E.; WIM, V.; HILDE, S.; DANY, B.; ANNEMIE, E.; HILDE, $\mathrm{V}$. In search of the optimal $\mathbf{N}$ fertigation dose for 'Conference' pear tree. 2013. Disponível em: <www.bdb.be/Portals/0/docs/sci201310.pdf $>$. Acesso em: 23 out. 2015.

RAIJ, B. van. Fertilidade do solo e manejo de nutrientes. Piracicaba: International Plant Nutrition Institute, $2011.420 \mathrm{p}$.

RUFATO, L.; MARCON FILHO, J.L.; MARODIN, G.A.B.; KRETZSCHMAR, A.A.; MIQUELUTI, D.J. Intensidade e épocas de poda verde em pereira 'Abate Fetel' sobre dois porta-enxertos. Revista Brasileira de Fruticultura, Jaboticabal, v.34, n.2, p.475-481, 2012.
STERN, R.A.; DORON, I. Performance of 'Coscia' pear (Pyrus communis) on nine rootstocks in the north of Israel. Scientia Horticulturae, The Hague, v.119, p.252-256, 2009.

TOMAZ, Z.F.P.; RODRIGUES, A.C.; VERÍSSIMO, V.; MARAFON, A.C.; HERTER, F.G.; RUFATO, A. de R. Compatibilidade de enxertia de cultivares de marmeleiros com pereiras. Revista Brasileira de Fruticultura, Jaboticabal, v.31, n.4, p.1211-1217, 2009.

USDA/FAZ - United States Department of Agriculture/ Foreign Agricultural Service. Fresh deciduous fruit (apples, grapes, $\&$ pears): world markets and trade. 2015. Disponível em: $<\underline{\text { https:// }}$ public.govdelivery.com/accounts/USDAFAS/ subscriber/new $>$. Acesso em: 19 ago. 2015.

YIN, F.X.; SEAVERT, C.F.; BAI, J. Nitrogen and phosphorus fertigation on pears. Western Nutrient Management Conference, Salt Lake City, v.7, p.135-140, 2007.

YIN, X.; BAI, J.; SEAVERT, C. F. Pear responses to split fertigation and band placement of nitrogen and phosphorus. HortTechnology, Alexandria, v.19, n.3, p.586-192, 2009.

YIN, X.; HUANG, X.L.; ROUX, J.L. Effects of integrated nitrogen fertilization and irrigation systems, rootstocks, and cultivars on productivity, water and nitrogen consumption, and mineral nutrition of pear. Agricultural Sciences, Irvine, v.3, n.2, p.257-267, 2012. 